\title{
Lisianthus 'Double Joy' -- Five Colors of Double-Flowering and Heat-Tolerant Cultivars Released by the University of Florida's Lisianthus Breeding Program ${ }^{1}$
}

\section{Brent K. Harbaugh and Zhanao Deng ${ }^{2}$}

In 1985, When we started a breeding program for lisianthus [Eustoma grandiflorum (Raf.) Shinners; Gentianaceae Juss.] at the University of Florida's Gulf Coast Research and Education Center Bradenton, Florida, the emphasis was on development of single flowering, pot or bedding plant types with heat tolerance and basal branching. At that time, cut flowers with single flowers were the most prominent type of lisianthus being grown in the United States, and evaluation of the potential of lisianthus as a pot crop generally was with single-flowering types (Halevy and Kofranek, 1984; Roh et al., 1989). Single flowers are still more popular than double flowers in cut-flower markets in Europe and Japan, but double flowers have become the most popular in the United States cut-flower markets. Presently, over $80 \%$ of the lisianthus grown for cut-flowers in the United States are double-flowering types. Double flowers typically have two to five rows of petals compared to a single row with five petals in single flowers. The original double flowers were natural mutations found by Japanese growers (Ohkawa, personal communication). Since double flowering types had such a high acceptance in the United States, we started a program in 1995 to breed our heat tolerance into double flowering pot types.

High temperatures during the seedling stage cause rosetting, or the formation of a basal cluster of leaves with no flowering stems, in lisianthus (Harbaugh et al., 1992; Harbaugh, 1995; Ohkawa et al., 1991; Ohkawa et al., 1994; Pergola, 1992), and cultivars differ significantly in their sensitivity to high temperatures (Fukuda et al., 1994; Harbaugh et al., 1992; Li et al., 2002). 'Maurine Blue' (Harbaugh and Scott, 1996) and 'Florida Blue' (Harbaugh et al, 1996) were the first heat-tolerant lisianthus whose seedlings could be grown at $28-31^{\circ} \mathrm{C}\left(82-88^{\circ} \mathrm{F}\right)$ without rosetting. The UF Double Joy cultivar group is intermediate in height between the Florida cultivar group and the Maurine cultivar group.

Double-flowering types are not yet available in the Maurine and Florida cultivar groups. While a few double-flowering pot type lisianthus cultivars have recently been released by commercial seed

1. This document is ENH1067, one of a series of the Environmental Horticulture Department, Florida Cooperative Extension Service, Institute of Food and Agricultural Sciences, University of Florida. Original publication date February, 2007. Visit the EDIS Web Site at http://edis.ifas.ufl.edu.

2. Brent K. Harbaugh, professor, and Zhanao Deng, assistant professor, Gulf Coast Research and Education Center, Florida Cooperative Extension Service, IFAS, University of Florida, Gainesville, FL 32611.

The Institute of Food and Agricultural Sciences (IFAS) is an Equal Opportunity Institution authorized to provide research, educational information and other services only to individuals and institutions that function with non-discrimination with respect to race, creed, color, religion, age, disability, sex, sexual orientation, marital status, national origin, political opinions or affiliations. U.S. Department of Agriculture, Cooperative Extension Service, University of Florida, IFAS, Florida A. \& M. University Cooperative Extension Program, and Boards of County Commissioners Cooperating. Larry Arrington, Dean 
companies in the US market, to our knowledge the UF Double Joy cultivars are the first double-flowering and heat-tolerant cultivar group. The UF Double Joy types are represented with five colors including blue, pink, white, blue rim, and pink rim (Fig. 1).

\section{Selection Procedures}

Growing conditions used to select seedlings for resistance to heat-induced rosetting during development of heat-tolerant parents included: (1) production during summer months under greenhouse conditions at day temperatures $\geq 35^{\circ} \mathrm{C}$, (2) exposure of 2- to 4-week-old seedlings to $28^{\circ} \mathrm{C}$ for 4 weeks in a growth chamber for initial selections in early generations, and (3) exposure of 17-day-old seedlings to $31^{\circ} \mathrm{C}$ in a growth chamber for 5 weeks for selection of final parents used in $\mathrm{F}_{1}$ hybrids. The photosynthetic photon flux in growth chambers was 150-190 umol $\cdot \mathrm{m}^{-2} \cdot \mathrm{s}^{-1}$ from cool-white fluorescent bulbs.

Heat tolerance as well as vegetative and flower characteristics of the Double Joy cultivar group were compared to seven commercial bedding or pot type cultivars. Seeds of all cultivars were planted on 19 January 2005, at Bradenton, Fla. Seventeen-day-old seedlings were grown either in a glasshouse (control) with a high of 30 to $33^{\circ} \mathrm{C}$ day and 13 to $15^{\circ} \mathrm{C}$ night or at a constant $31^{\circ} \mathrm{C}$ for 5 weeks in a growth chamber (heat-stressed). Seedlings exposed to $31^{\circ} \mathrm{C}$ were rated as rosetted if they had not bolted after growth for an additional 4 weeks in the control greenhouse. Non-rosetted plants from the control greenhouse were evaluated for plant height, plant width, number of branches (lateral stems forming on the central stem from the basal leaves to the first flower), total number of flowers and buds per plant after three flowers were open, petal length, and the number of days from sowing to flowering.

The most important and distinguishing attribute of all the 'Double Joy' cultivar group cultivars as compared with other commercial lines was their heat tolerance (Table 1). 'Florida Silver' was an exception, but it was released from our program as a semi-dwarf and heat-tolerant line and is now commercialized (Harbaugh et al., 1996). None of the heat stressed Double Joy cultivar group rosetted, while 70\% 'Forever White', 97\% 'Lisa Lavender', 100\% 'Lizzy Pink', 97\% 'Mermaid Lilac Rose', 86\% 'Sapphire Blue Chip', and 53\% 'Tiramisu Double Violet' seedlings rosetted.

In addition to heat tolerance, we considered that the UF Double Joy cultivars exhibited sufficient similarities in flower form and display, branching habit, and in the number of days from sowing to flowering to be included in the Double Joy cultivar-group. Notable differences were that plant height ranged from 38 to $48 \mathrm{~cm}$ for all UF Double Joy cultivars except 'UF Double Joy Pink' was $55 \mathrm{~cm}$, and 'UF Double Pink Rim' flowered 119 days from sowing compared to 115-116 days for the other UF

\section{Characteristics and Use}

UF Double Joy cultivars are intended to be used as flowering potted plants in containers $\geq 15-\mathrm{cm}$ diameter pots. Plant height for Maurine cultivars averaged 75 to $102 \mathrm{~cm}$ (Harbaugh and Scott, 1998) and Florida cultivars 28 to $35 \mathrm{~cm}$ (Harbaugh and Scott, 2001). Thus the UF Double Joy cultivars were intermediate in height averaging 39 to $55 \mathrm{~cm}$. Treatment with growth retardants is necessary for production of UF Double Joy cultivars in $\leq$ 15-cm-diameter pots (Harbaugh et al., 1998). Three to four plugs per $15-\mathrm{cm}$-diameter pot are recommended for optimal marketing display.

\section{Literature Cited}

Fukuda, Y., K. Ohkawa, K. Kanematsu, and M. Korenga. 1994. Classification of Eustoma grandiflorum (Raf.) Shinn. cultivars on rosette characteristics based on the bolting ratios after a high temperature treatment. J. Jpn. Soc. Hort. Sci. 62:845-856.

Halevy, A. H. And A. M. Kofranek. 1984. Evaluation of lisianthus as a new flower crop. HortScience 19:845-847.

Harbaugh, B. K. 1995. Flowering of Eustoma grandiflorum (Raf.) Shinn. cultivars influenced by photoperiod and temperature. HortScience 30:1375-1377. 
Harbaugh, B. K., M. S. Roh, R. H. Lawson, and

B. Pemberton. 1992. Rosetting of lisianthus cultivars exposed to high temperatures. HortScience 27:885-887.

Harbaugh, B. K. and J. W. Scott. 1996. Maurine Blue lisianthus [Eustoma grandiflorum (Raf.)

Shinn.]. HortScience 31:1055-1056.

Harbaugh, B. K. and J. W. Scott. 1999. Florida Pink and Florida Light Blue - Semi-dwarf heat-tolerant cultivars of lisianthus. HortScience 34:364-365.

Harbaugh, B. K. and J. W. Scott. 2005 a. Maurine Dawn-A heat-tolerant lisianthus with pink/white bicolored flowers. HortScience 40:858-860.

Harbaugh, B. K. and J. W. Scott. 2005b. Florida Blue Frill and Florida Pink Frill-Semi-dwarf heat-tolerant lisianthus with bicolored flowers. HortScience 40:861-863.

Harbaugh, B. K., J. W. Scott, and D. B. Rubino. 1996. Florida Blue semi-dwarf lisianthus [Eustoma grandiflorum (Raf.) Shinn.]. HortScience 31:1057-1058.

Li, J., Y. Notsu, M. Ogawa, H. Ohno, and K. Ohkawa. 2002. Rosetting characteristics-based on classification of Eustoma grandiflorum (Raf.) Shinn. cultivars sown on different dates. (Japanese text with English abstract) Environ. Control in Biol.

40:229-237.

Ohkawa, K., A. Kano, K. Kanematsu, and M. Korenaga. 1991. Effects of air temperature and time on rosette formation in seedlings of Eustoma grandiflorum (Raf.) Shinn. Scientia Hort. 48:171-176.

Ohkawa, K., T. Yoshizumi, M. Korenaga, and K. Kanematsu. 1994. Reversal of heat-induced rosetting in Eustoma grandiflorum with low temperatures. HortScience 29:165-166.

Pergola, G. 1992. The need for vernalization in Eustoma russellianum. Scientia Hort. 51:123-127.
Roh, M. S., A. H. Halevy, and H. F. Wilkins. 1989. Eustoma grandiflorum, p 322-327. In A. H. Halevy (ed.). Handbook of flowering. Vo. VI. CRC Press, Boca Raton, Fla.

Royal Horticultural Society. 1966. Royal Horticultural Society colour chart. Royal Hort. Soc., London. 


\section{'UF DOUBLE JOY' Series}

\section{Lisianthus}

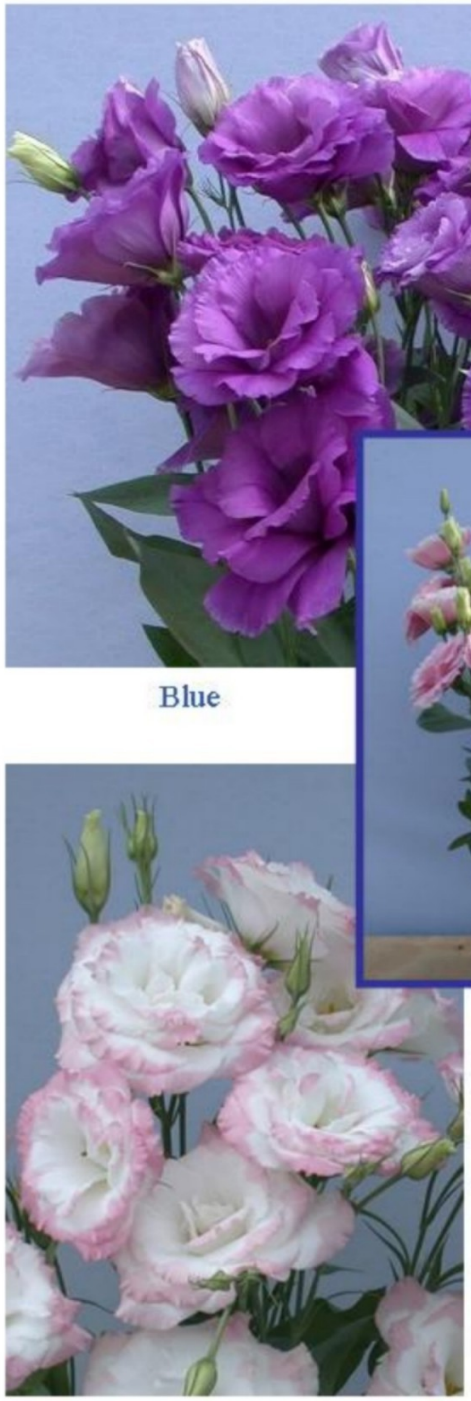

Pink Rim

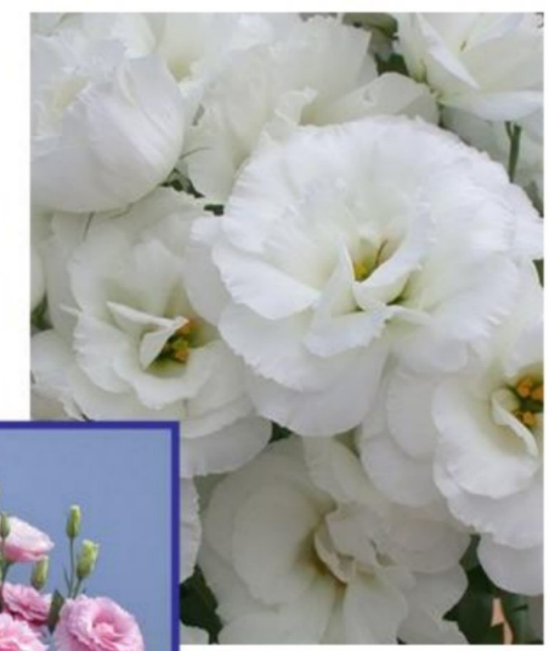

UNIVERSITY OE FLORIDA IFAS
White

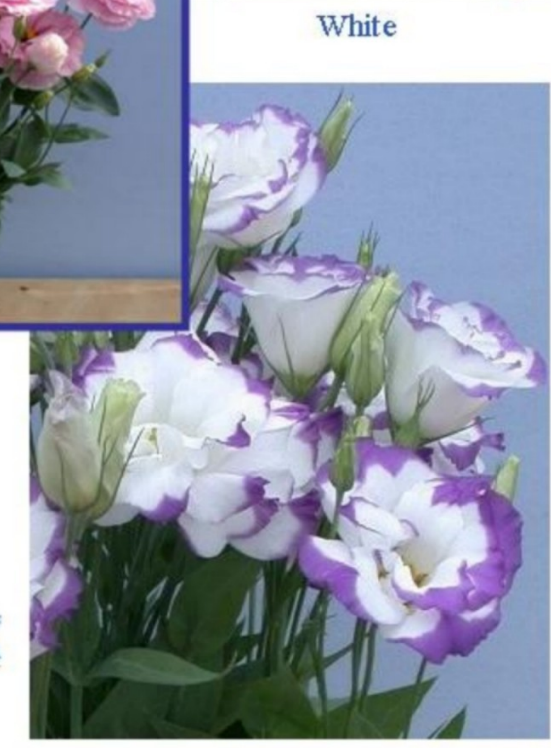

Blue Rim 
Table 1. Percentage rosetted plants ${ }^{z}$ and growth and flowering characteristics ${ }^{y}$ of twelve lisianthus cultivars grown in 11.5 -square-cm pots (0.65-L) at Bradenton, Florida.

\begin{tabular}{|c|c|c|c|c|c|c|c|}
\hline \multirow[b]{3}{*}{ Cultivar } & \multicolumn{4}{|c|}{ Plant $^{2}$} & \multirow{3}{*}{$\begin{array}{l}\text { Flowers } \\
\text { and buds } \\
\text { (no.) }\end{array}$} & \multirow{3}{*}{$\begin{array}{r}\text { Petal } \\
\text { length } \\
(\mathrm{cm})\end{array}$} & \multirow{3}{*}{$\begin{array}{l}\text { Days } \\
\text { to flower } \\
\text { (no.) }\end{array}$} \\
\hline & \multirow{2}{*}{$\begin{array}{c}\text { Rosetted } \\
\text { (\%) }\end{array}$} & \multirow{2}{*}{$\begin{array}{l}\mathrm{ht} \\
(\mathrm{cm})\end{array}$} & \multirow{2}{*}{$\begin{array}{l}\text { width } \\
(\mathrm{cm})\end{array}$} & \multirow{2}{*}{$\begin{array}{c}\text { Branches } \\
\text { (no.) }\end{array}$} & & & \\
\hline & & & & & & & \\
\hline Florida Silver & 0 & 37 & 23 & 11 & 80 & 6.2 & 114 \\
\hline Forever White & 70 & 31 & 20 & 12 & 56 & 5.9 & 112 \\
\hline Lisa Lavender & 97 & 29 & 20 & 7 & 49 & 5.9 & 108 \\
\hline Lizzy Pink & 100 & 31 & 20 & 8 & 54 & 5.6 & 116 \\
\hline Mermaid Lilac Rose & 97 & 28 & 18 & 8 & 55 & 5.8 & 112 \\
\hline Sapphire Blue Chip & 83 & 28 & 19 & 11 & 66 & 5.5 & 107 \\
\hline Tiramisu Double Violet & 53 & 39 & 21 & 7 & 43 & 5.4 & 119 \\
\hline UF Double Joy Blue & 0 & 40 & 21 & 9 & 44 & 5.8 & 116 \\
\hline $\begin{array}{l}\text { UF Double Joy Blue } \\
\text { Rim }\end{array}$ & 0 & 38 & 20 & 11 & 59 & 5.6 & 116 \\
\hline UF Double Joy Pink & 0 & 55 & 16 & 8 & 38 & 5.9 & 116 \\
\hline UF Double Joy White & 0 & 39 & 23 & 10 & 67 & 5.6 & 115 \\
\hline $\operatorname{LSD}(P=0.05)$ & 11 & 3.5 & 4.7 & 2.1 & 9.2 & 0.4 & 3 \\
\hline $\begin{array}{l}{ }^{z} \text { Seventeen-day-old se } \\
\text { for } 4 \text { weeks. Percentag } \\
\text { arranged in a randomiz } \\
{ }^{y} \text { Vegetative and floweri } \\
\text { night. Values are mear } \\
\text { design. } \\
{ }^{\circ} \text { Plant height = distance } \\
\text { w } \text { Lateral stems forming }\end{array}$ & $\begin{array}{l}\text { gs were exp } \\
\text { rosetted pla } \\
\text { ock design. } \\
\text { haracteristic } \\
\text { five replicati } \\
\mathrm{n} \text { the pot rim } \\
\text { he central st }\end{array}$ & $\begin{array}{l}d \text { to } 31^{c} \\
\text { are me } \\
\text { ofe for } p \\
\text { of singl } \\
\text { the tip c } \\
\text { rom the }\end{array}$ & $\begin{array}{l}5 \text { weeks } \\
\text { three re } \\
\text { grown in } \\
\text { t experin } \\
\text { ighest b } \\
\text { l leaves }\end{array}$ & $\begin{array}{l}\text { growth cha } \\
\text { ations with e } \\
\text { reenhouse a } \\
\text { tal units arra } \\
\text { measured af } \\
\text { he first flowe }\end{array}$ & $\begin{array}{l}\text { ber and the } \\
\text { ht plants as } \\
33 \text { to } 35^{\circ} \mathrm{C} \\
\text { ged in a con } \\
\text { three flow }\end{array}$ & $\begin{array}{l}\text { rown in a } \\
\text { experim } \\
\text { and } 13 \text { t } \\
\text { etely rand } \\
\text { had oper }\end{array}$ & $\begin{array}{l}\text { enhouse } \\
\text { I unit } \\
{ }^{\circ} \mathrm{C} \\
\text { zed }\end{array}$ \\
\hline
\end{tabular}

